\title{
Police Accountability and Human Rights at the Italian Borders
}

\author{
Giuseppe Campesi (University of Bari "Aldo Moro")
}

\begin{abstract}
Over the last twenty years Italy has developed a complex policy model for the surveillance of its maritime borders. This model entails the involvement of different agencies, acting under their own peculiar mandate and rules of engagement, as well an expanding geopolitics of border controls, taking place into a wide frontier zone which expands from the high sea to the network of processing centres near main disembarkation points. Recent policy developments, such as the adoption of a code of conduct for NGOs vessels performing search and rescue in the Strait of Sicily, the controversial cooperation with Libyan authorities and the implementation of the so called 'hotspot approach', have increased public concerns in relation with the risk of migrants being denied the right to seek asylum, or suffering from arbitrary detention, excessive use of force or other ill treatments. The aim of this chapter is to explore extent to which existing judicial, disciplinary and political accountability procedures are sufficient to prevent, and eventually to sanction, human rights violations committed by immigration law enforcement and security agencies during border surveillance and screening procedures at disembarkation points.
\end{abstract}

\section{Introduction}

The strengthening of border controls has intensified the structural violence exercised by borders. This has certainly increased the risk migrants face in their attempt at circumventing controls, putting their lives in danger along always more perilous and complex routes (Spijkerboer 2007; Weber, Pickering 2011; Shields 2015; Guild 2017), but it has also increased the risks of violation of their human rights by putting under strain the rule of law principles (Mitsilegas 2015). As it was emphasized by the United Nations High Commissioner for Human Rights (OHCHR), "policies aimed not at governing migration but rather at curtailing it at any cost, serve only to exacerbate risks posed to migrants, to create zones of lawlessness and impunity at borders, and, ultimately, to be ineffective" (OHCHR 2014).

Contemporary border control can negatively impact on a wide range of human rights, from the right to asylum and prohibition of torture and inhuman and degrading treatment, to the rights to privacy and data protection as well as non-discrimination (Mitsilegas 2015). In relation with the specific context of border control and surveillance at sea, a report by the EU Fundamental Rights Agency (2013) has highlighted that migrants are in particular at risk of:

- having their right to life endangered, especially in the maritime context and in relation to the need to provide adequate assistance to persons in distress;

- suffering from excessive use of force and other ill treatments, both on board of rescue vessels and at disembarkation points, where the processing of migrants intercepted or rescued at sea is usually carried out; 
- being denied the right to seek asylum and thus exposed to the risk of refoulment both as a consequence of border surveillance practices and the eventual cooperation with third countries in the context of maritime surveillance, and as a consequence of an inadequate system at main disembarkation points to properly identify protection needs at the borders;

- being arbitrarily detained in breach of Article 5 of the European Convention of Human Rights after disembarkation and in relation with administrative procedures following the irregular crossing of the borders.

In light of the numerous risks of human rights violations related to border control policies, the OHCHR has underlined the importance of putting in place adequate mechanisms for exercising effective judicial and political control over border control practices. In particular, it has encouraged the states at developing forms of independent monitoring of human rights at international borders and establishing or strengthening systematic reporting mechanisms, in order to ensure that all migrants who have suffered human rights violations or abuses as a result of border governance measures have equal and access to justice, or other effective remedies providing adequate and prompt reparation for the harm suffered (OHCHR 2014).

Border control policies have greatly evolved over the last two decades, becoming one of the most relevant activities in which the police forces of main western countries are currently engaged, although working in a complex network of relations with other public and private agencies (Weber, Bowling 2004; Weber 2006). Given the extreme vulnerability of migrants and asylum seekers to potential breaches of their human rights, and the extensive and ever-increasing powers over their personal freedoms border police are entrusted with, the effective protection of human rights at the borders is strongly related with the degree of accountability of law enforcement and security agencies performing border control functions. In this chapter, I will try to understand if and to what extent the current accountability regime of the police and other security forces involved in the control and surveillance of Italian maritime borders is adequate to ensure effective protection of migrants' human rights. In order to do this, I will first develop a typology of police accountability regimes and then I will explore in more details the accountability regime of the Italian police forces. Later I will use this analytical grid in order to evaluate whether the Italian police accountability regime is adequate to meet the challenges to the protection of migrants' human rights at the Italian maritime borders.

\section{Police accountability regimes}

Policing is one of the main public service provided by the state. The police have the task of guaranteeing peace and internal order, concepts that in a democratic polity generally coincide with the idea of guaranteeing human rights and fundamental freedoms of individuals. To fulfil this function, police are entrusted with extensive executive and coercive powers (Bittner 1970; Klockars 1985), powers that could be easily abused. Any action (or omission) of the police that violates legal rules is commonly defined as 'police misconduct', but this concept encapsulates a quite heterogeneous group of activities (or omissions) (Kutnjak Ivkovic 2014). Police misconducts may range from corruption, to excessive use of force. Moreover, given the inherently intrusiveness of the power police are entrusted with, their misconduct in many cases amount to a violation of basics human rights. The risk of police misconduct is typically considered higher when 
police activity involves contacts with individuals characterised by low socioeconomic status or otherwise particularly vulnerable.

How society regulates and controls the organization of the police and the exercise of the powers they are entrusted with is commonly considered a crucial indicator of the democratic nature of the political and social order (Jones, Newburn, Smith 1996: 187). This is commonly referred to as 'police accountability', which means that "the police accept being questioned about their decisions and actions and accept the consequences of being found guilty of misconduct, including sanctions and having to compensate victims" (UNDOC 2011: 9).

'Accountability' is nevertheless an inherently complex concept. Broadly understood it refers to ideas such as 'answerability', 'responsiveness', 'openness' and 'efficient management', indicating both democratic policy-making and responsibility of those called upon to implement state policies. With specific reference to police accountability, Jones (2012: 694) has distinguished between the two different dimensions of 'organisational' and 'individual' accountability. The first refers to the democratic control exercised over the organization of policing, the statutory definition of the powers police are entrusted with and the elaboration of their strategic priorities; the second refers to the process through which potential misconducts are prevented, identified and responded to after the act. While 'individual' accountability is certainly related to 'organizational' accountability, given that both the institutional and political context may impact on police officers' action, it largely depends on distinct procedures and mechanisms aimed at preventing human rights abuses and providing effective remedies when human rights standards are violated in practice.

The idea of 'remedies' against human rights violations include two different dimensions, the first being related with the process through which complaints on alleged human rights violations are heard, investigated and decided by competent bodies, the second with the outcome of the procedure and the measures taken in response to an actual or potential violation of human rights (Shelton 2015: 16). The existence of remedial institutions and procedures to which victim may have access is expressly recognised by international and regional human rights instruments ${ }^{1}$, therefore states need to establish a mechanism whereby people can seek redress if their rights have been violated. According to a common understanding of 'effective remedy', states shall ensure to individuals accessible, effective, and enforceable remedies to vindicate their rights establishing appropriate independent judicial and administrative mechanisms for addressing claims of rights violations under domestic law and making reparation to individuals whose rights have been violated.

The possibility to file a complaint against the police is a clear indicator of high standards of accountability and is likely to help police in restoring or enhancing public confidence (ECHR 2009: 6; UNDOC 2011: 33; Johansen 2013: 446). This notwithstanding, from a socio-political point of view police accountability cannot be reduced to the legal notion of 'effective remedy'. Even when considered in the restricted sense of 'individual' accountability, this should be considered as a conglomerate of different regimes were compensation and prevention should go hand in hand. In an attempt at building a typology of police accountability regimes, I will first distinguish between

\footnotetext{
${ }^{1}$ See Article 8 of the Universal Declaration on Human Rights; Article 2(3) of the International Covenant on Civil and Political Rights; Article 13 of the European Convention on Human Rights; Article 47 of the EU Charter of Fundamental Rights.
} 
internal/external mechanisms, depending on whether the procedure is run by the police themselves or is placed under the responsibility of an independent body, and reactive/proactive mechanisms, depending on whether the procedure may be triggered by the autonomous investigation of the oversight body or on account of a complaint filed by the individual concerned or other stakeholders. I will then further distinguish accountability regimes according to the measures taken in response to an actual or potential violation of human rights and the envisaged purpose of the remedies offered to victims of police misconduct.

Under internal procedures, police misconduct is investigated by the police themselves and accountability is assured through the chain of command (disciplinary control) or by setting up oversight bodies to which abuses may be reported (internal complaint mechanisms). Disciplinary procedures represent a traditional layer of misconduct control that are activated proactively by supervisors but are often too focused on assuring officers' compliance with superior's orders or with standard operational procedures, while the victims' interests are not always taken in consideration, nor are they considered legitimate parties to the proceedings. A disciplinary offence is essentially seen as a 'neglect of duty' and treated as such, though when the individual misconduct amount to a criminal offence a judicial proceeding can run in parallel to the internal disciplinary procedure. The police may also establish complaint mechanisms in order to deal with cases of misconduct reported by individuals. While characterized by a certain degree of civil involvement or established as separate internal affairs unit in order to dispel public concerns on their ability to carry out unbiased and unpartisan investigations, internal complaint bodies are nevertheless part of the police organisation and thus inherently exposed to the risk that police solidarity can prevent adequate accountability (Prenzler, Ronken 2001).

External accountability procedures are usually more credible in the eyes of the public as not affected by police esprit de corps. One of the most important external accountability procedure is judicial control over police exercise of executive and coercive powers, through which police is in fact held accountable to the law. The relationship between law and policing is absolutely central to the idea of the accountability of policing (Dixon 1992). The judiciary may exercise control on the legitimacy of police action both ex ante, when the recourse to executive and coercive powers must be previously authorised by a judge, or ex post, when the steps taken by the police need to be judicially validated. Police are also accountable to the judiciary when their misconduct amount to criminal offence or cause a damage to a third party. A legal suit may be filed against individual police officers, or even against the agency as a whole, to seek redress for the damage suffered due to officers' misconduct. While civil litigation is considered as one of the strongest deterrents against police misbehaviour (Smith 2003), research has shown that in many jurisdictions police officers are covered by insurances or otherwise protected from paying the financial consequences of their misconduct (Chevigny 1995). When police misconduct amount to a criminal offence, prosecutorial power of investigation can usually be exercised ex officio, or as a consequence of a complaint received from the individual concerned or other stakeholders. Unfortunately, given the high standard of proof of the criminal justice system, its inherently limited accessibility and traditional professional links between prosecutorial offices and the police, only a small amount of police misconducts results in prosecution and eventually conviction (Skolnick, Fyfe 1993).

Besides judicial remedies, complementary non-judicial bodies may be authorised to oversight police action and receive complaints on police misconduct. According to what has been defined as the 'civilian review model' (Prenzler, Ronken 2001), an external agency may be called to monitor 
internal investigations conducted by the police, eventually with the power to conduct its own investigation in most controversial cases. In other cases, a fully independent non-judicial body may be established with the power to receive and investigate complaints on police misconduct. In many countries specialised external police complaint bodies have been established in recent years (Johansen 2013), while in other countries national institutions for the promotion and protection human rights may include in their mandate the oversight of police activities. In order to be considered effective, non-judicial complaint and oversight bodies should respect a number of requirements that have been recently established as benchmarks at the international level (UN General Assembly 1993; ECHR 2009; UNDOC 2011). According to these principles, non-judicial complaint and oversight bodies should be independent from the executive and enjoy a complete discretion in the exercise of their oversight prerogatives, they should also have the capacity to conduct investigations and gather evidence, and ensure victims involvement in the procedure by at the same time protecting them from potential intimidation and reaction from law enforcement officials (which is a particularly sensitive issue in case of detained complainants).

Non-judicial remedies should nevertheless not be considered as substitute for ordinary judicial or disciplinary procedures. Even when non-judicial oversight bodies are vested with the power to receive and investigate individual complaints, they generally lack the capacity to prosecute or sanction the individual concerned and must instead report misconducts to competent authorities for a judicial or disciplinary follow up. Through their oversight function and the correlative power to initiate investigations on their own, human rights and police complaint bodies are important tools for facilitating access to effective remedies to victims of police misconduct, especially when these are in a particular weak position as being themselves implicated in illicit activities, or otherwise exposed to police reprisal.

The primary purposes of the remedies offered against police misconduct should be to rectify the wrong done and correct injustice. This is the main reason behind the possibility to challenge before a judge the exercise of executive powers by the police when this may affect directly individuals' human rights. Offering redress to victims is the most common solution especially in cases when rectification is no longer possible. Compensation restore victims' welfare and reaffirms their rights, though in many cases the injuries caused by human rights violations are intangibles and difficult to measure, while victims' desire for revenge needs to find satisfaction through a public condemnation of perpetrators. In criminal and disciplinary proceedings, the purpose of the remedy offered to victims is the condemnation of police misconduct. Punishment does not constitute a restitution or a compensation to the victim, but it is the way through which the binding force of rules is reaffirmed, and perpetrators are deterred to commit further wrongs. The sanctions applicable in disciplinary proceedings typically range from verbal warnings, written warnings, cuts in salary, working without pay, demotion and dismissal. Though they are usually less intrusive than criminal sanctions, such as fines or imprisonment, in many circumstances may have a stronger deterrent effect than a remote possibility to incur in a criminal conviction.

Some (McLaughlin, Johansen 2002; Smith 2004) see the satisfaction of victims' desire for revenge as inappropriate purpose of accountability procedures, regarding mediation and restoration as more effective that a purely investigate-and-prosecute approach to complaints. This is especially so when it is difficult to produce clear evidence of facts leading to disciplinary or criminal charges, or in those cases when it is apparent that complainants are more interested in an immediate acknowledgement of the wrong suffered than in remote punishment. 
An effective system of police accountability will need much more that a complaint mechanism, this is especially so as police misconduct often amount to human rights violations which are inherently different from purely private injuries. Remedies for public wrongs must be seen, then, as serving not only private redress but public policy, as an important means of promoting police compliance with human rights standards (Shelton 2015: 61). The need to prevent future misconduct should be a central concern in the functioning of oversight and complaint mechanisms, whereby forward-looking strategies aimed at early detection and at providing sufficient guarantee of non-repetition must be put in place. In particular, complaint mechanisms should function as learning process providing useful guidance in identifying patterns of misconduct and developing organisational remedies, such as the revision of operational standards and/or of working conditions, for preventing their occurrence in the future.

\section{Police accountability in Italy}

Italy has traditionally had a very complex institutional framework for maintaining peace and internal order, an endeavor to which several law enforcement and security agencies contribute (Bellavita 1962; D'Orsi 1972). According to Italian law², other agencies alongside State Police are called to perform functions as "police forces" for the purpose of protecting public order and internal security, this being the Carabinieri and the Guardia di Finanza, which are both gendarmerie-type forces with military status and officially belonging to the armed forces (Chiappetti 1987; Corso 1996) 3 $^{3}$ Moreover, in the last decades of the twentieth century the functions performed by armed forces have clearly expanded beyond the mere defense of the State from external military threats (Edmundus 2006; Easton et al. 2010), an evolution that in Italy has been consolidated with the reform of the military law in 2010, which in particular cases ${ }^{4}$ attributes to armed forces (in particular the Army and the Navy) also responsibilities in the protection of public order and internal security of the state (Chiti 2017).

This complex institutional framework greatly complicates the accountability regime of the Italian police. In spite of the fact that in performing their duties for the protection of public order and internal security all police forces are functionally dependent from the Ministry of the Interior, the Italian gendarmeries are subject to military discipline and jurisdiction, depending for their administrative organization to different Ministries ${ }^{5}$. This may produce a lack of coordination among police forces, somewhat complicating the lines of their political accountability.

All the personnel of the agencies performing function as police forces are public employees, therefore subject to the general rules of public service, though a number of specific rules regulate their status. These rules greatly accentuate the bond of subordination to superiors, producing what the Italian legal scholars have traditionally defined as a kind of 'special submission' (Baldanza 2003: 344; Caia 1996: 346) to the chain of command. This is particularly true for 'militarized' police forces, given that discipline "constitutes the fundamental rule for military personnel" and is

\footnotetext{
${ }^{2}$ Article 16 Law No 121/1981.

${ }^{3}$ For a definition of 'gendarmerie' see Lutterbeck 2013.

${ }^{4}$ Article 93, Legislative Decree No 66/2010.

${ }^{5}$ While the Carabinieri are directly dependent from the Ministry of Defense, the Guardia di Finanza is traditionally dependent from the Ministry of Finance.
} 
commonly considered the "main factor of cohesion and efficiency" of the armed forces (Bortolotti 1989; Malinconico 1990) ${ }^{6}$. But it is also true of the State Police, the only Italian 'civilian' security force, which in fact continues to be organized according to a principle of strict hierarchical subordination that clearly differentiates it from other sectors of public administration, bringing it closer to the model of the armed forces (Carrata 1986).

In spite of the attempts at their 'democratization', the first carried out in 1978, with the reform of the principles on 'military discipline' ${ }^{7}$, and the second in 1981 with the 'de-militarization' of State Police $^{8}$, Italian law enforcement and security agencies thus retain their traditional hierarchical and disciplinary structure. All police officers, both civil and military, are subject to particular duties of subordination $^{9}$ being required to execute the orders received form their hierarchical or operational superior ${ }^{10}$, so much so that the failed or delayed execution of an order is considered a crime $^{11}$, as well as having disciplinary consequences. The reforms enacted in 1978 and 1981 have however tried to dilute the principle of hierarchical subordination, affirming that obedience should not be blind and absolute, but 'conscious' (Bortolotti 1989; Carrata 1986). This means that police officers must not under any circumstances execute orders that 'manifestly' constitute a criminal offence, reporting them to superiors ${ }^{12}$, while they 'must' request explicit confirmation of the orders that appear in breach of the law ${ }^{13}$. In all circumstances in which they were allowed to question the legitimacy of the order received, police officers remain responsible for the criminal offences committed in the execution of it ${ }^{14}$.

This raises the problem of the attitude the officer must assume when an order is given which, although not constituting 'manifestly' a criminal offence, nevertheless represents a potential violation of the rights of the individuals concerned. The legitimacy of the order can be questioned, but if the order is confirmed the officer will still be subject to the duty of obedience. In these cases, the norms regulating police officers' behavior clearly favor the principle of hierarchical subordination and this in light of the alleged need to assure the efficiency of the administrative action. This is nevertheless done at the expenses of the protection of the rights of those who could suffer the consequences of the illegitimate action of police forces, whose protection is ultimately left to the competence and good will of the high-ranking officials. More generally, it is difficult to avoid the impression that police officers are required to assume two somewhat incompatible attitudes: obey promptly and at the same time reflect on the legitimacy of the orders received (lafrate 2016: 320). All this in an institutional context where also military or militarized bodies, within which disciplinary pressure is particularly strong, are called to perform police functions. It is therefore highly probable that the tendency to obey will prevail over the ability of police officers

\footnotetext{
${ }^{6}$ Article 1346, Legislative Decree No 66/2010.

${ }^{7}$ Law No 382/1978, then refused in the new Military Code, Legislative Decree No 66/2010.

8 Law No $121 / 1981$.

${ }^{9}$ Article 65, Law No 121/1981 and Article 1346(3), Legislative Decree No 66/2010.

${ }^{10}$ Article 66, Law No 121/1981 and Article 1347, Legislative Decree No 66/2010.

${ }^{11}$ Article 72, Law No 121/1981 and Article 173, Italian Military Criminal Code for Times of Peace.

${ }^{12}$ Article 66(4), Law No 121/1981 and Article 1349(2), Legislative Decree No 66/2010.

${ }^{13}$ Article 66(3), Law No 121/1891 and Article 729(2) Presidential Decree No 90/2010.

${ }^{14}$ Article 51, Italian Criminal Code.
} 
to identify the potential illegitimacy of the orders received, thus reducing the capacity of the system to prevent potential police misconducts.

To compensate for the increased risk of breach of individuals' human rights that the typical hierarchical and disciplinary structure of Italian police entails, a strong and effective regime of police accountability would be required. But unfortunately, it is precisely what Italy is still lacking.

The powers attributed to police forces and the scope of their action, in particular as regards the possibility of limiting the human rights of individuals, are essentially determined in Italy by the Constitution and by the guarantees on the protection of individual liberties there enshrined (Chiappetti 1987; Corso 1996). According to the Italian Constitution, the police can affect individuals' fundamental freedoms only within the limits established by law, while in many cases the exercise of its executive or coercive powers is explicitly subject to judicial review, in the sense that it must be authorized ex ante by a judge, or otherwise validated ex post when, in case of necessity, the police was forced to act without a previous judicial authorization. This is particularly true for the exercise of powers that affect individuals' personal liberty, given that any deprivation or limitation of it should be regulated by law and exercised under strict judicial oversight ${ }^{15}$.

As public employees, all members of Italian police forces, civil or military, are subject to the ordinary rules on civil and criminal liability for acts committed in violation of rights and damages caused to third parties or to the administration ${ }^{16}$. The individual responsibility of the police officer subsists whether the breach has been caused by a wrongful action or by an omission or unjustified delay in the execution of duties ${ }^{17}$, but when a damage has been caused by an officer during his service, the administration is also held responsible for the injuries suffered by third parties and can claim against the officer only if he has acted in breach of his duties ${ }^{18}$. On the basis of this principle of 'organic identification' between the public employee and the administration, it is rare for the individual police officer to be called to personally compensate for the damages suffered by third parties. But of course, the situation is different when the damage is the consequence of a criminal offence, as this produces a caesura in the institutional link between the individual officer and the public administration.

As mentioned, all police officers are subject to ordinary criminal jurisdiction for common crimes, with the sole exception of the right to serve any sentence to imprisonment in a military penal establishment ${ }^{19}$. Crimes committed by police officers can be reported by anyone to the prosecutorial authorities and are generally prosecuted ex officio. Some categories of crimes of particular concern for the prevention of police misconduct are nevertheless prosecuted only if the victim files a complaint, and this may reduce access to justice especially for victims in a socially and politically weak position. This is for example the case of police ill-treatment and excessive use of force, which according to Article 582 of the Italian Criminal Code cannot be prosecuted if the victim has not filed a complaint, and this, according to the UN Human Rights Committee, produce

\footnotetext{
${ }^{15}$ Article 13, Italian Constitution.

${ }^{16}$ Article 28, Italian Constitution.

${ }^{17}$ Article 23, Presidential Decree No 3/1957.

${ }^{18}$ Articles 22 and 18, Presidential Decree No 3/1957.

${ }^{19}$ Article 79, Law No 121/1981 and Article 63, Italian Military Criminal Code for Times of Peace.
} 
a situation of substantial impunity for police and law enforcement officials (UN Human Rights Committee 2017: § 21).

Under another point of view, police officers are instead subject to more stringent controls than ordinary citizens, since superiors have the duty to report to the prosecutorial authorities any criminal offence committed by their subordinates ${ }^{20}$. Furthermore, police officers may be suspended from the service for the duration of the criminal proceedings, and in the event of a final conviction for particularly serious crimes they may also be demoted or dismissed (Carrata 1986; Malinconico 1990). All this produces a substantial intersection between judicial and disciplinary control over police action.

The disciplinary proceeding remains however distinct from the criminal proceeding, although the latter may have direct disciplinary consequences. The term "disciplinary offence" means any conduct of a police officer who fails to comply with the regulations or with an order received ${ }^{21}$. Disciplinary sanctions range from punishments with an eminently 'moral' or 'corrective' purpose, such as oral or written warnings, to suspension form service, demotion or dismissal sanctioning most serious misconducts. The military personnel can also be subjected to disciplinary sanctions amounting to a deprivation of liberty, which much of the Italian legal scholars (Malinconico 1990: 287; Bortolotti 1989: 2) now consider in clear breach of the rule set forth by the Italian Constitution on the protection of personal liberty.

In spite of the attempts made over the years at clarifying and specify the rules on police officers' good conduct, high-ranking officials are still vested with a huge discretional power in defining what actually consists of a disciplinary offence (Carrata 1986: 169; Bortolotti 1989: 4). The disciplinary control system of the Italian security forces is in fact more a means of assuring the officers' compliance with superior's orders, than a mechanism for protecting the rights of third parties. Individual misconduct is thus essentially treated as a form of insubordination and viewed only from the point of view of the need to ensure internal discipline. So much so that disciplinary offences can be reported only by hierarchical superiors and the disciplinary proceedings is entirely entrusted to internal bodies, scarcely distinguished from the hierarchical lines of command, who carry out the investigation and decide the case without any possibility for participation of or control from third parties. Except for acts which amount to a criminal offense and for which a criminal proceeding has been initiated, there is no guarantee that an individual misconduct will lead to open a disciplinary proceeding and eventually to a punishment.

In many respects this system of legal, judicial and disciplinary accountability is not adequate to compensate for the increased risks of police misbehavior deriving from the typical hierarchical and 'paramilitary' structure of Italian police forces. While it cannot be argued that in strict legal terms Italy is devoid of 'effective remedies' against the breach of fundamental rights committed by police officers, it must be emphasized that the only existing independent external control over police action, that is judicial control, it is quite difficult to be accessed, especially for people in particular conditions of vulnerability or weak social position. Disciplinary control, on the other hand, is completely impermeable to any involvement of external third parties. Individuals can in no way submit complaints, nor is there any independent body that can in any way receive, investigate, decide a complaint or stimulate the hierarchies to investigate alleged misconducts

${ }^{20}$ Article 331, Italian Code of Criminal Procedure.

${ }^{21}$ Article 11, Presidential Decree No 737/1981 and Article 1352, Legislative Decree No 66/2010. 
committed by police officers. This is clearly the expression of an anachronistic conception of disciplinary control, which is seen more as tool for ensuring officers' subordination to the hierarchies, than as instrument for preventing potential breaches of the human rights of individuals concerned by police action.

Beyond these traditional instruments of police accountability, there are no other way in Italy to make law enforcement and security agencies accountable for their misconducts. Besides having never established an independent police complaint body, following the experience of other European countries, Italy is also a devoid of a general independent National Human Rights Body, and has been urged by the UN Human Rights Committee to "expeditiously establish a national human rights institution in compliance with the principles relating to the status of national institutions for the promotion and protection of human rights (the Paris Principles)" (UN Human Rights Committee 2017: § 7). A bill proposing the establishment of such an institution was being discussed in Parliament during the previous legislature ${ }^{22}$, but it is unclear what will be its fate after the general elections of March 2018, that saw a change in the ruling coalition.

Having ratified the Optional protocol to the UN Convention against torture in $2012^{23}$, Italy has now identified the National Ombudsman on the Rights of Detainees ${ }^{24}$ as its National Prevention Mechanism under the Protocol. The Ombudsman has been established in $2013^{25}$, but has become fully operational only in 2016, with the appointment of the members of its Collegiate Panel. It exercises its mandate with full independence from the executive, even if its staff is provided by the Ministry of Justice. The Ombudsman is vested with the power to visit all places of custody, including those placed near main disembarkation points or dedicated to the custody of irregular migrants in the process of being deported, but it cannot receive and process individual complaints. Despite this, its role remains of great importance in preventing police misconducts, particularly in light of its power di publish reports and issue recommendations to the Italian government on how to prevent torture and other ill treatments in all places of custody. In addition to this, the Ombudsman has recently been vested with the power to monitor forced repatriations in compliance with Article 8(6) of the Directive 2008/115/EC.

During the past legislature, a number of Parliamentary Commissions ${ }^{26}$ and especially the Extraordinary Commission on Human Rights established by the Senate in 2013 in partial compensation for the lack of a proper Human Rights Body ${ }^{27}$, have carried out inspections, inquiries and published reports addressing the issue of the protection of human rights in relation with law enforcement action. Although not explicitly conceived as a tool to collect and process complaints on individual cases of police misconduct, Parliamentary commissions have somewhat

\footnotetext{
${ }^{22}$ Senate of the Republic, Bill No S-1908.

${ }^{23}$ Law No 195/2012.

${ }^{24}$ Garante nazionale dei diritti delle persone private della libertà personale, see: http://www.garantenazionaleprivatiliberta.it/gnpl/ (last accessed: August 2018).

${ }^{25}$ Article 7, Decree No 146/2013.

${ }^{26}$ The Parliamentary Commission of Inquiry on the Facilities for the Reception and Detention of Migrants (established in November 2014) had played a role in monitoring police activities in place of custody for migrants, and the permanent Commission on National Defense of the Senate has occasionally explored the role of the Navy in controlling Italian external borders.

27 Senate of the Republic, Motion No 1-00007, Session No 13, April 16, 2013.
} 
compensated for the shortcomings of the current Italian police accountability regime, holding the executive at least politically responsible for law enforcement and security forces action. The problem is that some of these Parliamentary commissions do not deal with human rights breaches and police misbehavior on a permanent basis, while the Extraordinary Commission on Human Rights established by the Senate is temporary, although a motion approved in July 2018 has suggested the possibility to replace it with a permanent Human Rights Commission that should somehow act as Human Rights Body ${ }^{28}$.

\section{Border policing, accountability and human rights in Italy}

Over time Italy has developed a complex institutional apparatus for the control of irregular migration by sea, further strengthening it with the adoption of the Law No. 189/2002 that amended the Legislative Decree No 286/1998, the Italian Consolidated Law on Immigration. Italian Law explicitly conceives the control of irregular migration by sea as an 'interagency' task whose strategic leadership is assigned to the Interior Ministry. The latter has the duty of promoting coordination between the relevant Italian authorities and EU agencies, as well as, in coordination with the Ministry of Foreign Affairs, of promoting agreements with countries of origin and/or transit aiming at fostering the "cooperation in the fight against illegal immigration"29. In 2002, a new Central Direction for Immigration and Border Police (CDIBP) was established under the Department of Public Security at the Ministry of Interior, which was entrusted with the overall coordination of border control policies.

The arrangements for coordination between the different law enforcement and security agencies that, under the leadership of the CDIBP, are entrusted by the law with the task of enforcing controls at maritime borders were further specified in 2003 with the enactment of a Ministry of Interior's decree which identified three main strategic dimensions for the control of irregular migration by sea.

The first dimension are activities carried out in countries of origin and/or transit, eventually under the umbrella of bilateral cooperation agreements ${ }^{30}$. According to a model that many defined as 'extraterritorial' border governance (Cremona and Rijpma 2007; Mitsilegas 2010), the aim of the cooperation is to anticipate control activities by acting in foreign territorial waters, so as to intercept the movement of vessels carrying migrants even before they can leave the jurisdiction of the country of origin and/or transit. The EU has in recent years sought to incorporate the cooperation in the field of migration control within the diplomatic framework of its wider neighbourhood policies (Lavenex 2006; Jeandesboz 2009), but in spite of these attempts bilateral cooperation between member-states and their closest neighbours remains a key in the organization of 'local border control regimes' in the Euro-Mediterranean region (Kasparek, Wagner 2012).

The second dimension are activities carried out in international waters, where the Italian Navy is called to exercise its prerogatives in the monitoring, surveillance, identification and control of

\footnotetext{
${ }^{28}$ Senate of the Republic, Motion No 1-00003, Session No 19, July 19, 2018.

${ }^{29}$ Article 11-bis, Legislative Decree No 286/1998.

${ }^{30}$ Article 2(1), Ministry of Interior Decree of 14 July 2003.
} 
"naval targets" at sea and in the fight against "illegal immigration" 31 . The Italian Navy has traditionally been the key actor in the surveillance of the high sea, since the late nineties being also increasingly mobilized for the control of irregular migration. This is one of the most relevant examples of the involvement of the Italian armed forces in the implementation of law enforcement policies, which has been officially authorized with the enactment of the Law No $189 / 2002$. Since then the Italian Navy has put into place a permanent activity at sea "aimed at the localization, identification and tracking of vessels suspected of smuggling, through the use of all the available aero-naval equipment" (Ministero per i rapporti con il Parlamento 2004: 112). Since 2004, the Italian Navy is also deployed on a permanent basis for the control of irregular migration in the Strait of Sicily, and occasionally in the lower Adriatic and in the Ionian Sea.

The third dimension are activities carried out in territorial waters and the contiguous zone, where border controls and immigration law enforcement are mainly entrusted to the Guardia di Finanza ${ }^{32}$, whereas the Coast Guard is responsible for the coordination of search and rescue ${ }^{33}$. The Guardia di Finanza has traditionally played the role of customs police, being mainly concerned with economic crimes such as contraband and tax evasion. Over the years its remit has been extended to cover all cross-border challenges, ranging from undocumented migration to trafficking in drugs and arms. The Guardia di Finanza is now entrusted with the exclusive responsibility for border controls at sea in the territorial waters and the contiguous zone (Ministero dell'Interno 2000: 176), and its para-military apparatus, originally developed for the fight against the smuggling of illicit drugs, has been gradually upgraded and converted to the control of irregular migration by sea. Since 2006, the action of the Guardia di Finanza is further supported by the action of the EU agency Frontex, which over the last ten years has launched a number of joint operations in the Central Mediterranean region, focusing mainly on the patrol of the Strait of Sicily (Campesi 2015: 176-85).

A fourth strategic dimension in the control of irregular migration by sea may be identified in the administrative procedures carried out by the Italian State Police in the processing centers located near the main disembarkation points. Italy has been equipped with first aid and reception facilities since the mid-1990s, when the first processing centres were established according to Decree No 451/1995. These facilities, originally labelled as Centri di Primo Soccorso e Assistenza (CPSA) - of which Lampedusa is undoubtedly the most well-known - are usually run by private bodies and other NGOs, to which the Ministry of Interior contract out the providing of services, while the processing of incoming migrants is performed by Italian State Police which, in cooperation with the Italian Army, is also responsible for security and public order inside ${ }^{34}$. Unfortunately, Italian law has never clarified the main features of such facilities, which in theory were designed to accommodate migrants just landed on Italian shores for the time strictly necessary for first aid and identification. Over the years CPSAs had acquired the characteristics of secure facilities, where migrants waited in detention for several weeks before being released or transferred to other reception facilities. This had happened in the absence of any judicial oversight, and this is one of the reasons why many had described CPSAs as "legal black holes" where migrants' habeas corpus

\footnotetext{
${ }^{31}$ Article 3(2), Ministry of Interior Decree of 14 July 2003.

${ }^{32}$ Article 3(1), Ministry of Interior Decree of 14 July 2003.

${ }^{33}$ Article 2(2), Ministry of Interior Decree of 14 July 2003.

${ }^{34}$ Article 9, Circular Order of the Ministry of Interior No 12700/2014.
} 
was systematically violated (Vassallo Paleologo 2012; Campesi 2013). A point of view also confirmed by the European Court of Human Rights in the Khlaifia case ${ }^{35}$.

In 2015, in the wake of rapid increase in the number of incoming migrants by sea and in order to make checks at main disembarkation points more effective and ensure a proper implementation of the rules on the registration of irregular migrants and asylum-seekers set forth by the Regulation (EU) No 603/2013, the EU Commission has launched the so called 'hotspot approach' (Neville et al. 2016). The plan drawn up with the adoption of the EU Agenda on Migration (European Commission 2015a), and developed with the publishing of a number of subsequent policy papers (European Commission 2015b; 2015c), was presented as a tool designed to "assist" Greece and Italy to "swiftly identify, register and fingerprint incoming migrants" (European Commission 2015a: 6). It has been officially implemented in Italy with the enactment of the Legislative Decree No 142/2015 and of the Decree No 13/2017, which partly revised the legal basis for the reception of migrants after disembarkation. According to Article 8 of Legislative Decree No. $142 / 2015$, the "first reception" of those reaching Italian shores should be carried out in the facilities already set up under the rules enacted in the mid-1990s (that is, in the old CPSAs), while according to the Article 17 of the Decree No 13/2017, every "foreigner" intercepted while attempting to irregularly cross the border or disembarked on the Italian soil as a result of rescue operations at sea, should be conducted "for the needs of first aid and assistance" to the "hotspot facilities" set up in the old CPSAs, or to other disembarkation points ${ }^{36}$, where "all identification and fingerprinting procedures are carried out", and information on the procedure for requesting international protection, on the relocation program and on the possibilities for voluntary return is provided.

The Italian border control strategy thus relies on the role played by different actors, operating at different institutional levels and in different operational contexts (see: Figure 1). This produces a complex geopolitics of border control and surveillance activities taking place into a wide frontier zone expanding from the high sea (or even foreign territorial waters), where Italian security forces cooperate with third countries' security forces and coast guard under the umbrella of a number of agreements and memorandum of understandings, to the network of processing centres existing near main disembarkation points and functioning according to the policy framework drawn with the implementation of the 'hotspot approach'. This complex border control apparatus is largely entrusted to the political responsibility of the Ministry of the Interior, which coordinates the operational activity of various law enforcement and security agencies, in particular of State Police, Guardia di Finanza and the Italian Navy, in addition to the Coast Guard, a special branch of the Italian Navy dependent on the Ministry of Transport and responsible for the Italian Maritime Rescue Coordination Center.

This apparatus suffers from a general lack of oversight mechanisms which derives from the inherently weak accountability regime of Italian police and security forces on which we focused in the previous section, but beyond this, two more specific blind spots of accountability in border control practices can be singled out here. One is related with the overall policy and operational

\footnotetext{
${ }^{35}$ Khlaifia and Others v. Italy, Application No. 16483/12, Final Judgment (Grand Chamber) Dec. 15, 2016.

${ }^{36}$ A policy paper published by the Italian Interior Ministry defines these as "mobile hotspots" where teams ready to be dispatched to different disembarkations points according to the needs may ensure the implementing of the "hotspot approach' also outside the places officially operating as 'hotspot facilities' (Ministero dell'Interno 2016: 7)
} 
framework in which border surveillance takes place; the other is related with the implementation of screening procedures at main disembarkation points.

[Figure 1 about here]

\section{Border surveillance}

Border surveillance takes place on the high sea or other out-of-sight locations where it is extremely difficult, if not impossible, to access justice before disembarkation. In the operational context of border surveillance performed by the Italian security agencies there is currently a complete lack of independent oversight mechanisms. Once rescued at sea and before disembarkation, migrants and potential asylum seekers are under the absolute and complete control of immigration law enforcement agencies and thus at risk of being refouled or of suffering for excessive use of force and other ill treatments without any possibility to file a complaint. Of particular concern in this case are the recent endeavours of the Italian Government aiming at establishing a stable cooperation with the Government of National Accord (GNA) led by Fayez AlSerraj and at reducing the role played by NGOs vessels in search and rescue activities in the Strait of Sicily (Heller, Pezzani 2018).

Immediately after the GNA was installed, the EU began negotiations to obtain its consent to an extension of the EU Common Defence and Security Mission "Eunavfor Med-Sophia" operations on Libyan territory, as well as the resumption of the technical assistance interrupted in 2013. Italy has strongly supported such diplomatic initiatives with the clear aim of concluding a cooperation agreement with Libya similar to the one signed between the EU and Turkey (Rettman, 2016). The negotiations focused on creating the preconditions necessary to operate in Libya with the cooperation of the new government's security forces. The emphasis has thus been placed on the need to rebuild Libya's security apparatus. As a result, in June 2016 "Eunavfor Med-Sophia" was finally extended for one year, with a significant extension of its mandate as it was entrusted with the task of providing technical assistance to the Libyan coast guard and navy. This function has been carried out in close cooperation with Frontex, which in the last months of 2016 began to train the Libyan coast guard (Frontex 2016). Meanwhile, Italy has made every effort to reach an agreement with the new Libyan government, finally agreeing a much-criticized MoU in February 2017 (Nielsen, 2017).

The steps taken by the Italian government were greeted with great favor by EU partners (European Council 2017), who immediately supported the Italian initiative by mobilizing 1.8 billion Euros from the EU Trust Fund for Africa for cooperation projects with Libya. Key for the EU and Italian strategy was the strengthening of the operational capabilities of the Libyan Coast Guard, which was expected to play a central role in managing Libyan maritime borders and ensure safe disembarkation on Libyan soil of migrants intercepted and rescued at sea (European Commission 2017). Italy, in particular, by signing a new MoU with Libyan authorities aimed at resuming cooperation on security and irregular migration according to past bilateral agreements. Since February 2017, the Libyan coast guard has thus been supported by the Italian authorities in its effort to take control of its search and rescue region, intercepting vessels upon departure and diverting them back on Libyan soil, where migrants are to be hosted in 'reception' centres pending their repatriation or voluntary return to their country of origin. 
The rate of migrants intercepted by Libyan authorities and disembarked on Libyan soil has thus increased steadily (Heller, Pezzani 2018: 53), this in the absence of any monitoring or accountability mechanisms ensuring that the resources and support provided to Libyan authorities to strengthen their search and rescue and migration control capacities are not contributing to human rights abuses. Serious concerns have instead been raised about the links between armed groups, criminal groups, and different coast guard factions, as documented in a report published by a UN panel of experts monitoring the political transition in Libya (UN Security Council, 2017). The report also described numerous violations of fundamental rights suffered by migrants hosted in 'reception' centres after interception at sea. Similar concerns have been expressed by some NGOs (Human Rights Watch 2017; Amnesty International 2017) and especially by the OHCHR which, in light of the 'horrific' reception conditions in Libya, has defined the policy of assisting the Libyan coast guard to intercept and return migrants in the Mediterranean as 'an outrage to the conscience of humanity' (OHCHR 2017).

In parallel with the increasing in the number of migrants intercepted by Libyan authorities, a violent campaign aimed at delegitimising, criminalising and ultimately ousting from the Central Mediterranean scenario the NGOs performing search and rescue activities was launched (Heller, Pezzani 2017). In the midst of this violent campaign, the Italian Government enacted a Code of Conduct officially to discipline non-governmental SAR activities but in fact compromising NGOs' ability to effectively conduct their humanitarian mission free of political interference (Cusumano 2017). These endeavours have not only produced an inversion in the role played by NGOs and Libyan Coast Guard, with the last one asserting aggressively its role as the main search and rescue actor in the Central Mediterranean, but have above all reduced the number of independent observers operating on the high sea. This has greatly complicated the possibility to produce evidence on potential human rights abuses perpetrated during border surveillance activities, as many of the most controversial incidents occurred over the last two years could be documented only thanks to the presence of NGOs vessels. The decrease in rescue NGOs presence has clearly left maritime space off the Libyan coast clear for the Libyan Coast Guard to intercept migrants and pull them back to Libya, but has also offered the possibility for Italian authorities to hand over the coordination of rescue activities to Libyan authorities, thus in fact implementing with impunity a strategy that the authors of the Mare Clausum report aptly defined as of 'refoulement by proxy' (Heller, Pezzani 2018: 66).

\section{Screening procedures at disembarkation}

Screening procedures at main disembarkation points take place under the framework of the so called 'hotspot approach', the implementation of which has sparked many criticisms especially as regards the risk of prolonged detention in absence of a clear legal provision and of any judicial oversight. In particular, many pointed out the weakness of the legal basis according to witch the 'hotspot approach' has been implemented in Italy (Penasa 2017; Benvenuti 2018). The plan of the Italian Government is in fact to channel all arrivals into the so called 'hotspot facilities' located near key "disembarkation points" where the new operating procedures (Ministero dell'Interno 2015; 2016) developed by the Italian government in accordance with what has been envisaged by the EU Agenda on Migration will apply. In spite of Article 11 of the Legislative Decree No 142/2015 describing these facilities as places that offer first aid and assistance to incoming migrants by sea, and Article 8 of the Decree No 13/2017 making reference to 'reception centres' as the places 
where all incoming migrants should be sent in order to be properly processed according to the rules set forth by the Regulation (EU) No 603/2013, 'hotspots facilities' have been in fact managed as secure facilities through which multiple control and containment functions are performed (Tazzioli 2017; Sciurba 2017).

The implementation of the hotspot approach has attracted much criticism also in relation to poor detention conditions, ill treatments during detention, insufficient provision of legal information and erroneous classification of potential asylum seekers as economic migrants during the preidentification stage, excessive use of force during the identification process, especially against those resisting fingerprinting (Amnesty International 2016; ECRE 2017; OXFAM 2017). The risks of violating migrants' fundamental rights during processing procedures after disembarkation are also greatly amplified by the fact that 'hotspot facilities' are not easily accessible and thus kept away from public scrutiny. In addition to being located in remote places or in 'militarized' areas, they cannot be freely accessed and anyone wishing to visit them must obtain an authorization from local police authorities according to the rules regulating access in immigration-related custodial facilities ${ }^{37}$.

In spite of the attempt at keeping hotspot procedures out of civil society oversight, the treatment received by migrants at main disembarkation points has attracted much attention, especially thanks to the monitoring function performed by NGOs and other international organisations providing support to migrants after their disembarkation ${ }^{38}$; by Parliamentary commissions of inquiry, which carried out a number of inspections, held hearings with high ranking official from the Ministry of Interior and published several reports which were widely debated (Senato della Repubblica 2014; 2017a; 2017b; Camera dei Deputati 2017); and finally, by the National Ombudsman on the Rights of Detainees, that has carried out several field visits and published several recommendations addressed at the Italian Government on detention condition in 'hotspot facilities' (Garante Nazionale dei diritti dei Detenuti 2017).

These oversight exercises have led to the denunciation of a number of illegal practices, forcing the Italian government to partially revise its operating procedures at main disembarkation points, especially as regards the practice of detaining migrants until the finalisation of the identification process and the possibility to made recourse to coercive means in order to win the resistance of those refusing fingerprinting. In particular, in 2017 has been finally clarified that resort to coercion is not authorized under any circumstances, and that those resisting fingerprinting can at most be 'sanctioned' with prolonged detention in one of the existing detention centers for irregular migrants $^{39}$. In spite of the somewhat positive impact on the Italian policy that these forms of political accountability have had, a number of question still need to be addressed, in particular as regards the weak legal framework in relation to pre-admittance detention, and the absence of any form of judicial oversight on it; but also as regards the absence of any systematic independent monitoring on disembarkation and screening procedures, especially when they take place outside the places that have been officially designed as 'hotspot facilities'.

\footnotetext{
${ }^{37}$ Article 6, Circular Order of the Ministry of Interior No 12700/2014.

${ }^{38}$ According to the 'Standard Operating Procedures for Italian Hotspots', UNHCR and IOM are admitted to access on a permanent basis 'hotspot facilities' in order to provide assistance and information on the asylum procedure and the possibility for voluntary repatriation to migrants (Ministero dell'Interno 2016: 24-25)
}

${ }^{39}$ Article 17(3) Decree No 13/2017. 


\section{Closing remarks}

Whether one is ready or not to consider states directly responsible for the human consequences of the structural violence exercised over migrants through their increasingly complex and sophisticated border control strategies, one can concede following Spijkerboer (2007) that being inherently dangerous for migrants' life, border control policies should be inspired by the humanitarian principle of 'harm reduction'. This means that states should consider themselves under the obligation to take all the preventive measures to safeguard the lives of those who are put at risk by the structural violence of border control policies. By bringing this argument a step further, one can also argue that states must also implement systems that reduce the risk of violating migrants' human rights during border surveillance and border control activities, especially by reinforcing the accountability of the security agencies involved and by improving the accessibility and effectiveness of the remedial system.

From the analysis of the Italian case an apparent paradox emerges. If we stick to the formal definition of 'legal remedy', one could certainly argue that Italy has in place a clear legal framework as regards the judicial accountability of law enforcement and security agencies, but this is by no way effective as remedial system for the protection of migrants' rights. The judicial system is costly, not easily accessible for individuals in a particular weak position and, given the high standard of proof required, hardly able to provide victims of police misconduct with a prompt and immediate redress. In its concluding observations to the sixth periodic report on Italy, the UN Human Rights Committee (2017) has underlined with concern the substantial impunity of Italian police forces in cases of alleged ill treatment and other instances of violations of human rights, in fact suggesting that judicial remedies are not always the most effective way to prevent police misconduct.

To make things worse, it must be remembered that in the case of border control policies, the road to judicial remedies is in some cases de jure or de facto precluded. As our analysis of Italian border control policies has showed, migrants detained at main disembarkation points are not in the condition to ask a judge a rectification of their unjust detention, while in the absence of systematic independent monitoring on border surveillance practices, many will be never in the condition to file a claim or report to the judiciary the violation of their human rights.

The main alternatives to judicial accountability are not adequately developed. The disciplinary accountability system is particularly backward, as it is essentially devoted at ensuring the internal discipline of law enforcement and security agencies, not at addressing the complaints filed by victim of police misconduct of other stakeholders, while, in spite of the National Ombudsman on the Rights of Detainees gradually positioning itself as a key agency for the monitoring of border control practices, especially when migrants are taken in custody by immigration law enforcement agencies, the absence of a National Human Rights Body makes it more complicated to exercise systematic and independent monitoring on a complex border control apparatus to which many different law enforcement and security agencies contribute.

In recent years the active role of the Italian Parliament and of civil society have provided for alternative forms of political accountability compensating for the lack or inadequacies of ordinary form of judicial and disciplinary accountability on law enforcement and security agencies. These forms of political accountability have proved to be somewhat effective in monitoring state 
practice, especially at main disembarkation points, triggering a learning process that stimulated a partial revision of the operating procedures adopted in the processing of incoming migrants. But these alternative accountability and oversight mechanisms continue to suffer from a number of gaps. In fact, border control and surveillance policies are often implemented in widely dispersed and 'out-of-sight' locations and operational contexts thus seriously limiting the effectiveness of the existing safeguards against potential human rights abuses at the Italian borders and of any attempt by civil society at keeping an eye on Governmental action. In conclusion, the peculiar geopolitics of border control policies exacerbates the rigidity of the Italian police accountability regime, which is largely based on the protection offered by the judicial system and lacks more flexible complaint or oversight mechanisms.

\section{Works cited}

Amnesty International. 2016. Hotspot Italy. How EU's Flagship Approach Leads to Violations of Refugee and Migrant Rights [online].

https://www.amnesty.org/en/documents/eur30/5004/2016/en/ (last accessed: August 2018).

Amnesty International. 2017. Libya's Dark Web of Collusion: Abuses Against Europe-Bound Refugees and Migrants [online]. https://www.amnesty.org/en/documents/mde19/7561/2017/en/ (last accessed: August 2018).

Baldanza, Andrea. 2003. "La difesa." Trattato di diritto amministrativo. Diritto amministrativo speciale. Volume 1. Le funzioni di ordine e le funzioni di benessere. Edited by Sabino Cassese. Milano: Giuffré, pp. 307-382.

Bellavita, Gino. 1962. Il paese delle cinque polizie. Torino: Edizioni di Comunità.

Benvenuti, Marco. 2018. Gli Hotspot come chimera. Una prima fenomenologia dei punti di crisi alla luce del diritto costituzionale. Diritto, immigrazione e cittadinanza [online] https://www.dirittoimmigrazionecittadinanza.it/archivio-saggi-commenti/saggi/fascicolo-n-22018-1/239-saggiobenvenuti (last accessed: August 2018)

Bittner, Egon. 1970. The functions of the police in modern society. A Review of Background Factors, Current Practices, and Possible Role Models.

Bortolotti, Dario. 1989. “Disciplina militare (diritto amministrativo)." Enciclopedia Giuridica. Volume XI. Roma: Treccani, pp. 1-10.

Caia, Giuseppe. 2003. "L'ordine e la sicurezza pubblica." Trattato di diritto amministrativo. Diritto amministrativo speciale. Volume 1. Le funzioni di ordine e le funzioni di benessere. Edited by Sabino Cassese. Milano: Giuffré, pp. 281-305.

Camera dei Deputati. 2017. Commissione parlamentare di inchiesta sul sistema di accoglienza, di identificazione ed espulsione, nonché sulle condizioni di trattenimento dei migranti e sulle risorse pubbliche impegnate. Relazione sul sistema di protezione e di accoglienza dei richiedenti asilo. Rome.

Campesi, Giuseppe. 2013. La detenzione amministrativa degli stranieri: storia, diritto, politica. Roma: Carocci. 
Campesi, Giuseppe. 2015. Polizia della frontiera. Frontex e la produzione dello spazio europeo. Rome: Deriveapprodi.

Carrata, Emiliano. 1986. "Pubblica sicurezza (sanzioni disciplinari)" Novissimo Digesto italiano. Appendice VI. Torino: Utet, pp. 167-172.

Chevigny, Paul. 1995. Edge of the knife: Police violence in the Americas. New York: New Press.

Chiappetti, Achille. 1987. "Polizia (dir. Pubblico)." Enciclopedia del diritto. Volume 34, Milano: Giuffreé, pp. 120-158.

Chiti, Edoardo. 2017. "Le sfide della sicurezza e gli assetti nazionali ed europei delle forze di polizia e di difesa." Sicurezza e libertà in tempi di terrorismo globale. Edited by Lorena Forni and Tiziana Vettor. Torino: Giappichelli, pp. 63-90.

Corso, Guido. 1996. "Polizia di sicurezza." Digesto delle discipline pubblicistiche. Volume XI. Torino: Utet, pp. 319-336.

Cremona, Marise, and Rijpma, Jorrit, "The Extra-Territorialisation of EU Migration Policies and the Rule of Law," EUI Working Papers: LAW 2007/01, 2007.

Cusumano, Eugenio. 2017. Straightjacketing migrant rescuers? The code of conduct on maritime NGOs. Mediterranean Politics: 1-9.

D’Orsi, Angelo. 1972. Il potere repressivo. La polizia. Feltrinelli: Milano.

Dixon, David. 1992. Legal Regulation and Policing Practice. Social \& Legal Studies (1): 515-541.

Easton, Marleen et al. 2010. Blurring Military and Police Roles. The Hague: Eleven International Publishing.

ECHR. 2009. "Opinion of the Commissioner for Human Rights concerning independent and effective determination of complaints against the police." Strasbourg: Document CommDH(2009)4.

ECRE. 2017. The implementation of the hotspots in Italy and Greece. A Study. [online] https://www.ecre.org/wp-content/uploads/2016/12/HOTSPOTS-Report-5.12.2016..pdf (last accessed: August 2018)

Edmundus, Timothy. 2006. What are armed forces for? The changing nature of military roles in Europe. International Affairs 82(6): 1059-1075.

European Commission. 2015a. Communication from the Commission to the European Parliament, the Council, The European Economic and Social Commitee and the Committee of the Regions. A European Agenda on Migration. Brussels (COM(2015) 240 final)

European Commission. 2015b. Communication to the European Parliament, the European Council and the Council. Managing the refugee crisis: immediate operational, budgetary and legal measures under the European Agenda on Migration. Brussels (COM(2015) 490 final).

European Commission. 2015c. Communication from the Commission to the European Parliament, the European Council and the Council, Managing the refugee crisis: State of Play of the Implementation of the Priority Actions under the European Agenda on Migration. Brussels (COM(2015) 510 final). 
European Commission. 2017. Action plan on measures to support Italy, reduce pressure along the Central Mediterranean route and increase solidarity. Brussels (SEC(2017) 339).

European Council. 2017. Malta Declaration by the members of the European Council on the external aspects of migration: addressing the Central Mediterranean route, Press Release 43/17.

Frontex. 2016. Frontex Helps Train Libyan Coast Guards. Press release [online] http://frontex.europa.eu/news/frontex-helps-train-libyan-coast-guard-zxRCnE (last accessed August 2018).

Fundamental Rights Agency. 2013. "Fundamental rights at Europe's southern sea borders." Luxemburg: Publications Office of the European Union.

Garante nazionale dei diritti dei detenuti. 2017. Rapporto sulle visite nei Centri di identificazione ed espulsione e negli hotspot in Italia. [online] http://www.garantenazionaleprivatiliberta.it/gnpl/resources/cms/documents/6f1e672a7da965c0 6482090d4dca4f9c.pdf (last accessed: August 2018)

Guild 2017, the dark side of globalization, in T. Gammeltoft-Hansen and J. Vedsted-Hansen (eds), Human rights and the dark side of globalisation: Transnational law enforcement and migration control, Routledge

Heller, Charles, and Lorenzo Pezzani. 2017. Blaming the Rescuers. [online] https://blamingtherescuers.org/report/ (last accessed: August 2018)

Heller, Charles, and Lorenzo Pezzani. 2018. Mare Clausum. Italy and the EU's undeclared operation to stem migration across the Mediterranean. [online] http://www.forensic-architecture.org/wpcontent/uploads/2018/05/2018-05-07-FO-Mare-Clausum-full-EN.pdf (last accessed: August 2018)

Human Rights Watch. 2017. Italy: Navy Support for Libya May Endanger Migrants [online] https://www.hrw.org/news/2017/08/02/italy-navy-support-libya-may-endanger-migrants (last accessed: August 2018).

lafrate, Cleto. 2016. Obbedienza, ordine illegittimo e ordinamento militare. Diritto e Questioni Pubbliche 16(2): 313-336.

Jeandesboz, Jean. 2009. "The Genesis of the European Neighbourhood Policy: Altenrative Narratives, Bureaucratic Competitions." The Frontiers of Governance: Understanding the External Dimension of EU Justice and Home Affairs. Edited by Balzacq, Thierry. New York: Palgrave Macmillan.

Johansen, Anja. 2013. "The Rise and Rise of Independent Police Complaint Bodies." The Future of Policing. Edited by Jennifer M. Brown. London: Routledge, pp. 446-462.

Jones, Trevor, Tim Newburn, and David J. Smith. 1996. Policing and the Idea of Democracy. British Journal of Criminology 36(2):182-98.

Jones, Trevor. 2012. "The Accountability of Policing." Handbook of Policing. Edited by Tim Newburn. London: Routledge, pp. 693-724.

Kasparek, Bernd, and Wagner, Fabian. 2012. "Local Border Regimes or a Homogeneous External Border? The Case of the European Union's Border Agency Frontex." The New Politics of International Mobility Migration Management and its Discontents. Edited by Geiger, Martin and Pécoud, Antoine. Osnabrück: Institut für Migrationsforschung und Interkulturelle Studien. 
Klockars, Carl B. 1985. The idea of police. Beverly Hills, CA: Sage Publications.

Kutnjak Ivkovic, Sanja. 2014. "Police Misconduct." The Oxford Handbook of Police and Policing. Edited by Michael D. Reisig, Robert J. Kane. Oxford: Oxford University Press, pp. 302-338.

Lavenex, Sandra. 2006. Shifting up and out: The foreign policy of European immigration control, West European Politics 29(2): 329.

Lutterbeck, Derek. 2013. The Paradox of Gendarmeries: Between Expansion, Demilitarization and Dissolution. Geneva: Centre for the Democratic Control of Armed Forces.

Malinconico, Carlo. 1990. "Disciplina militare." Digesto delle discipline pubblicistiche. Volume V. Torino: Utet, pp. 279-288.

McLaughlin, Eugene, and Anja Johansen. 2002. A Force for Change? The Prospects for Applying Restorative Justice to Citizen Complaints against the Police in England and Wales. British Journal of Criminology 42(3): 635-653.

Ministero dell'Interno. 2000. Relazione sull'attività delle forze di polizia e sullo stato dell'ordine e della sicurezza pubblica nel territorio nazionale (anno 1999). Rome: Senato della Repubblica, Camera dei Deputati.

Ministero dell'Interno. 2015. Roadmap italiana. [online] http://www.meltingpot.org/IMG/pdf/roadmap-2015.pdf (last accessed: August 2018)

Ministero dell'Interno. 2016. Standard Operating Procedures (SOP) for Italian Hotspots. [online] http://www.libertaciviliimmigrazione.dlci.interno.gov.it/sites/default/files/allegati/hotspots_sops _-_english_version.pdf (last accessed: August 2018)

Ministero per i rapporti con il Parlamento. 2004. Relazione sullo stato della disciplina militare e dell'organizzazione delle Forze armate (anno 2003). Rome: Senato della Repubblica, Camera dei Deputati.

Mitsilegas, Valsamis. 2015. "The law of the border and the borders of law: Rethinking border control from the perspective of the individual." Pp. 15-31 in Rethinking border control for a globalizing world: A preferred future, edited by Leanne Weber. London: Routledge.

Mitsilegas, Valsimis. 2010. "Extraterritorial Immigration Control in The 21st Century: The Individual And The State Transformed." Extraterritorial Immigration Control. Legal Challenges. Edited by Ryan, Bernard and Mitsilegas, Valsamis. Leiden: Martinus Nijhoff Publishers.

Neville, Darren et al. 2016. On the Frontline: The Hotspot Approach to Managing Migration. European Parliament, Policy Department for Citizen's Rights and Constitutional Affairs, Brussels.

Nielsen, Nicolaj. 2017. Italy and Libya cut migrant busting deal. Euobserver [online] https://euobserver.com/migration/136781 (last accessed: August 2018).

OHCHR. 2014. Recommended Principles and Guidelines on Human Rights at International Borders. New York (A/69/CRP. 1).

OHCHR. 2017. Suffering of migrants in Libya outrage to conscience of humanity [online] http://www.ohchr.org/EN/NewsEvents/Pages/DisplayNews.aspx?NewsID=22393\&LangID=E (last accessed: August 2018) 
Oxfam. 2016. "Hotspot, II diritto negato. Un sistema privo di cornice giuridica sta minacciando i diritti dei migranti che arrivano sulle coste italiane. Le richieste di Oxfam. [oniline] https://www.oxfamitalia.org/wp-content/uploads/2016/05/Rapporto_Hotspots_II-dirittonegato_Oxfam_DEF.pdf (last accesse: August 2018)

Penasa, Simone. 2017. L'aprroccio "hotspot" nella gestione delle migrazioni. Rivista AIC (2) [online]. http://www.rivistaaic.it/l-approccio-hotspot-nella-gestione-delle-migrazioni-quando-laforma-delle-fonti-diviene-sostanza-delle-garanzie-efficientismo-e-garantismo-delle-recentipolitiche-migratorie-in-prospettiva-multilivello.html (last accessed: August 2018)

Prenzler, Tim, and Carol Ronken. 2001. Models of police oversight: A critique. Policing and Society 11(2): 151-180.

Rettman, Andrew. 2016. EU navies prepare to start work in Libyan waters. Euobserver [online]. https://euobserver.com/foreign/133115 (last accessed: August 2018).

Sciurba, Alessandra. 2017. Categorizing migrants by undermining the right to asylum. The implementation of the "hotspot approach» in Sicily. Etnografia e ricerca qualitativa 10(1): 97-120.

Senato della Repubblica. 2014. Rapporto sui Centri di identificazione ed espulsione in Italia. Commissione Straordinaria per la Promozione e la Tutela dei Diritti Umani, XVII Legislatura, Rome.

Senato della Repubblica. 2017a. Rapporto sui Centri di identificazione ed espulsione in Italia (aggiornamento gennaio 2017). Commissione Straordinaria per la Promozione e la Tutela dei Diritti Umani, XVII Legislatura, Rome.

Senato della Repubblica. 2017b. Rapporto sui Centri di Permanenza per il Rimpatrio (aggiornamento dicembre 2017). Commissione Straordinaria per la Promozione e la Tutela dei Diritti Umani, XVII Legislatura, Rome.

Shelton, Dinah. 2015. Remedies in International Human Rights Law. Third Edition. Oxford: Oxford University Press.

Shields, Peter. 2015. "The Human Cost of the European Union's External Border Regime." Peace Review 27(1):82-90.

Skolnick, Jerome H., and James J. Fyfe. 1995. Above the Law: Police and the Excessive Use of Force. New York: Free Press.

Smith, Graham. 2004. Rethinking police complaints. British Journal of Criminology 44(1): 15-33.

Spijkerboer, Thomas. 2007. The Human Costs of Border Control. European Journal of Migration and Law 9(1):127-39.

Tazzioli, Martina. 2017. Containment through mobility: migrants' spatial disobediences and the reshaping of control through the hotspot system. Journal of Ethnic and Migration Studies: 1-16.

UN General Assembly. 1993. National Institutions for the Promotion and Protection of Human Rights. New York (A/RES/48/134).

UN Human Rights Committee. 2017. Concluding Observations on the Sixth Periodic Report of Italy. New York (CCPR/C/ITA/CO/6).

UN Security Council. 2017. Final report of the Panel of Experts on Libya established pursuant to resolution 1973(2011). New York (S/2017/466). 
UNDOC. 2011. "Handbook on police accountability, oversight and integrity." [online] https://www.unodc.org/pdf/criminal_justice/Handbook_on_police_Accountability_Oversight_and _Integrity.pdf (last accessed: August 2018)

Vassallo Paleogolo, Fulvio. 2012. Diritti Sotto Sequestro. Dall'Emergenza Umanitaria allo Stato di Eccezione. Roma: Aracne.

Weber Leanne, Sharon Pickering (2011). Globalization and borders: Death at the global frontier. Springer, 2011.

Weber, Leanne, and Benjamin Bowling. 2004. Policing migration: A framework for investigating the regulation of global mobility. Policing and Society 14(3): 195-212.

Weber, Leanne. 2006. "The shifting frontiers of migration control." Borders, mobility and technologies of control. Springer, Dordrecht, 2006. 21-43. 